\title{
Project Management Skills: A Literature Review and Content Analysis of Librarian Position Announcements
}

\author{
Jane Kinkus
}

\begin{abstract}
Project management is pervasive in the literature and practice of many industries, including finance, IT, engineering, and biotechnology. The recent rapid proliferation of complex library services such as virtual reference and digital repositories suggests that the role of librarians is becoming increasingly project-oriented. This article presents an overview of professional project management and a literature review from the library science and management literatures. A content analysis of librarian position announcements was conducted, and indicates that project management skills are in demand for librarians. However, it is unclear whether current library science literature and education adequately address project management skills or other traditionally "extra-librarian" leadership qualities now needed to effectively manage project based initiatives in libraries.
\end{abstract}

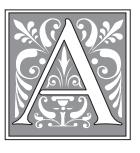

re project management skills in demand for librarians? Winston and Hoffman observe that the coverage of project management techniques in libraries has been scant, ${ }^{1}$ although the term "project management" can be found increasingly frequently in the literature of library science. For example, a search for articles from 2005 in the Wilson Library Literature and Information Science database returned 23 articles with the term "project management" in the subject field, over half of which were peer-reviewed. Articles with titles like "Project Management and Libraries," "Managing Your Library's Technology Projects," "Pace's Maxims for Homegrown Library Projects," and "Un- der Budget, on Time, and in Sync: How to Stage Successful Rollouts," indicate that librarians are interested in what project management is and how to do it. Library involvement with project management is also supported by the Association of Research Libraries' Office of Management and Leadership Services, which began offering a Library Project Management Institute in 1999 for anyone involved with project work in any capacity. Is being a good project manager simply a matter of being organized and able to tell people what to do, or is there more to it?

\section{Background on Project Management}

Librarians who work within the subject areas of business management, IT,

Jane Kinkus is Mathematical Sciences Librarian and Associate Professor of Library Science in the Purdue University Library; e-mail: jkinkus@purdue.edu. 
pharmaceuticals, or civil engineering are already aware that project management in these industries is a well-defined discipline, and that "project manager" (PM) is a specific job title for many professionals. In the formal sense, a project is an endeavor with definite starting and ending points that is undertaken to present a unique new product or service to customers. Project management can be defined as "The art of directing and coordinating human and material resources to achieve stated objectives within limits of time, budget, and stakeholders' satisfaction." ${ }^{2}$ Features of a project include cost, schedule, and technical parameters, and project results are often seen as building blocks in the execution of the strategic

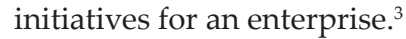

In addition to the US-based Project Management Institute (PMI), which has 100,000 members from 125 countries, ${ }^{4}$ there are at present several international project management professional associations in existence. The UK's Association for Project Management has 13,500 members from the UK and Europe, and the International Project Management Association in the Netherlands is composed of over 30 national associations representing over 20,000 project management professionals. ${ }^{5}$ There are at least fifteen project management journals in publication, several of which have started up in the past five years. Over thirty graduate schools in the United States offer master's degrees in or with concentrations in project management; both the PMI and the American Academy of Project Managers (AAPM) offer accreditation for academic programs in project management. ${ }^{6}$ For project managers who did not plan their PM career far enough in advance to earn a graduate degree before garnering their job title, several organizations offer project management certification, including the PMI, the AAPM, and the International Association of Project and Program Management. ${ }^{7}$ These organizations usually require applicants to have worked already as a project manager for a certain number of hours or years to be eligible to apply for certification. Certification also requires successful completion of a rigorous test or series of tests. Although certification or a graduate degree in project management is generally not required for a person to work as a project manager in most industries, certification is valuable because it provides evidence of both knowledge and experience. Demand for project management training and certification is growing, not least of all because the result of inadequate project management can have severe financial impact on the participants.

So, what is taught, and what type of knowledge is being tested, by the available sources of project management education and certification? One of the most widely used project management resources in current circulation is the PMI's Project Management Body of Knowledge (aka $P M B O K)$, a book that outlines the nine areas of competency considered essential for project management in any setting. ${ }^{8}$ In addition to the time management and cost management aspects of a project, the $P M B O K$ includes seven other knowledge areas that are key to project success. Scope management, which pertains to the definition of a project and sets boundaries for what problems will (and will not) be addressed by the project, is fundamentally intertwined with the project's timeline and budget. Risk management is an integral factor of the project planning process, and identified risk factors require constant monitoring throughout the life of the project. Human resource management reflects the project manager's ability to identify and acquire needed staff and to develop a productive team. Communications management refers not only to the project manager's competence in sharing information and feedback with the project team, but also in reporting progress and performance issues to key stakeholders. Procurement management, which is the ability to identify, solicit, and hire subcontractors for specific project segments, and quality management, which entails planning the standards of implementation 
and stakeholder satisfaction that must be achieved, comprise the most visible parts of project realization. The final stage of project implementation, integration management, includes final acceptance of the project, and absorption of the project results (that is, the new product or service) into the normal functions of the parent organization.

\section{Literature Review}

In some industries, the path to becoming a project manager is well defined, encompassing courses studied at the undergraduate or graduate level, on-thejob training, and even certification. It is widely acknowledged that good workers are often promoted to a managerial position based on their good performance in a nonmanagerial role. For example, in IT, programmers are often promoted to a managerial or supervisory position based on their performance as a programmer, often without receiving adequate training in the quite different responsibilities of a manager. Similarly, many new project managers find their way to PM responsibilities almost inadvertently. In a survey conducted by Greer, 100\% of managers who were questioned agreed with the statement, "In today's downsizing companies, more middle management positions are being eliminated and more task specialists are being asked to manage specific projects on a part-time basis (or in addition to their current task specialties)." ${ }^{\prime}$ The "instant" project manager is thus defined as "a manager whose skill set and main interest, prior to acquiring project management responsibilities, is that of a specialist in a particular field," and is someone who has been thrust into a role that requires taking charge of a project with little or no formal training. ${ }^{10}$ Greer proceeds to present a simplified summary of key project manager actions and their results as an industry-neutral, easy-to-understand guide for "instant" project managers in any field. ${ }^{11}$

While competency in specific knowledge areas, gained formally or on the fly, can imply that a project manager is well versed in practices that have become accepted as standard by the PM community, use of these tools and techniques alone is not sufficient to ensure success. Salah El-Sabaa, a professor of project management at the University of Cairo, conducted a study in which 85 project managers from a variety of organizations and industries were asked to list the personal characteristics, traits, and skills of the best project managers they knew. ${ }^{12}$ The survey answers were analyzed, and from them the researchers were able to identify 18 major skill items that fell into three main categories: human skills, conceptual and organizational skills, and technical skills. In the second phase of the study, 126 project managers were asked to rank the 18 skill items in importance. The most important types of skills as identified by the project managers in the study were human skills, which include the project manager's ability to motivate staff; listen to, understand, and persuade others; delegate authority; and exhibit political sensitivity. Conceptual and organizational skills (which include skills of planning and organizing, the ability to see the project as a whole, and the ability to visualize the project in relation to the organization and the industry) ranked slightly lower than human skills. And technical skills, such as specialized knowledge of tools or techniques in the industry, were ranked lowest in importance. Further, the project managers in the study consistently ranked human skills as highest in importance, and technical skills as lowest, regardless of the specific industry or sector they represented.

The importance of soft skills is discussed widely in the management literature. For example, while outlining the skills and practices of successful managers, Bolton asserts: "The emphasis of the future has to be in the leadership and interpersonal skills that ensure sound project-management practices. Projects fail because relationships and expectations fail."13 Taylor's A Survival 
Guide for Project Managers addresses the human skills needed for successful project management to at least the same, if not greater, degree than technical tools. ${ }^{14}$ Taylor states that project managers do not have to be specialists in the project's technology, in part because generalists have a better chance of understanding a project holistically without getting bogged down by technical details; subject experts are more prone to holding a narrower point of view. ${ }^{15}$ Further, increase in global competition and the extraordinary growth in information technology have created other problems for project managers-problems that have more to do with human relations than with technical skills. Now there is much more demand on the project manager's interpersonal and negotiating skills than there was just a few years ago. One of the reasons is that many organizations, including many libraries, have a matrix organizational structure in which project teams function within a more traditional hierarchical management structure. Instead of team members' being completely dedicated to a project for its duration, project teams in a matrix organization are composed of members from various departments who maintain other outside (that is, nonproject) responsibilities in addition to the project. Therefore, the project manager may not have functional authority over every team member, necessitating the use of interpersonal skills not only to build teams and morale, but also to get buy-in and to finesse support from other managers who are not stakeholders in the project but whose staff are involved. Taylor also reports on research done by Posner to learn what factors were most likely to cause problems for project managers during a project, and what personal characteristics make for above-average project managers. ${ }^{16}$ The eight major categories of problems were inadequate resources, unrealistic schedules, unclear goals, uncommitted team members, inadequate planning, communications breakdowns, goal and resource changes, and interdepartmental conflicts. Of the skills that make a superior project manager, six categories of skills were compiled from the respondents' answers. Five of the six categories deal with interpersonal skills: communication skills, organizational skills, team building skills, leadership skills, and coping skills. Similar to El-Sabaa's study, technical skills ranked lowest in importance. Posner also correlated the problems encountered by project managers to the skills needed for success, implying that most project problems are caused at least in part by a deficiency in an interpersonal skill. ${ }^{17}$ Taylor goes on to declare that the most important skill a project manager can exhibit is the ability to communicate effectively with others, not only because a project manager is a contact point among team members, other managers, customers, vendors, and others, but also because communication skills underpin other important skills, such as team building and leadership skills. ${ }^{18}$

Frank Cervone, a librarian at Northwestern University, has written a series of project management articles for librarians. Cervone states, "Project management is a challenge for many digital library projects because many librarians do not come from a background that accepts and embraces project management concepts." ${ }^{19}$ While Cervone's first article presents some general project management techniques tailored to library settings, his subsequent two articles focus on the human side of project management. The second article introduces a methodology for project managers to lead their project teams through the decision-making process. ${ }^{20}$ At first glance, Cervone's decision-making methodology can be seen as a simple set of steps that help a project team define a problem, identify and evaluate options, and implement a decision. However, upon subsequent reading, it can be seen that the reason project managers may require a decision-making methodology is that they need to navigate the sea of feelings and fears that team members and other stakeholders may feel when faced 
with a situation that requires a decision to be made. As a template for the process of continual communication between the project manager and team members, as well as between the project manager and stakeholders, and the recursive give and take of ideas and information among the team, Cervone's seven steps ultimately help the project manager allay doubt among key players by systematically making sure that all opinions are listened to and that all issues, both technical and emotional, are addressed before a decision is made.

In a third article on project management in libraries, Cervone highlights the importance of the project manager's skill at influencing others, especially when the use of a sound decision-making methodology fails to end in consensus. ${ }^{21}$ Influencing means getting one's way in an unobtrusive manner and is often done indirectly and subtly. While direct methods of persuasion may seem to be more aboveboard, the use of more understated influencing techniques can help a project manager establish a longlasting good rapport with key players by asking questions, listening actively while suspending judgment, stressing benefits from the other's perspective, and continually working toward a decision. ${ }^{22}$ In addition to outlining specific techniques of influencing, Cervone also stresses the importance of recognizing personality type and understanding the communication strengths and weaknesses of the predominant personality types as important tools in the good manager's communications toolbox. With regard to the most difficult aspect of project management, Cervone states, "Many people think technology is the issue, but the complexity is more typically in the relationships between the various people involved in the project. You can be a more effective project manager by continuously using and developing behaviors that enhance your ability to influence others." ${ }^{23}$

Garstang emphasizes practices the project manager can adopt to help the team members enjoy working on the project. ${ }^{24}$ While few PM articles discuss the importance of having fun in project management, Garstang encourages project managers to find ways to make teamwork enjoyable as a way to increase morale, which in turn can precipitate increased levels of creativity, productivity, and quality. Being a fun (and effective) project manager can also ensure that team members are more willing to work with the project manager on subsequent projects. $^{25}$

\section{Motivation}

In early 2003, a group of PUL staff and faculty began implementing a new digital reference service, a goal that supported both the libraries' and the university's strategic goals. The group and its work were ad hoc in nature, and the new digital reference service had to be rolled out on a tight four-month deadline. The team was not given a monetary budget, but the libraries administration had purchased a digital reference software package that had been recommended through preliminary team work, and additional costs of the implementation in the form of libraries staff labor were absorbed by the organization. The team's leader, a librarian who had been involved in previous project work in a corporate setting, recognized that her responsibilities as team leader implicitly included project management skills. She also knew that professionals in other industries are often trained in project management before being assigned to manage a complex technical project like the digital reference implementation. Her thoughts on this subject led to conversations with other members of the team. The librarians involved with the project could not recall learning about project management when they earned their MLS degrees. A consensus among the group was that the work undertaken in modern academic libraries seems to becoming more project-based, and while everyone had already been involved in at least one project-based effort at PUL, 
nobody in the group had received any onthe-job training in project management. While in search of validation from the library science literature that librarian jobs are becoming more project-oriented, the author discovered a 2002 article by Karen Croneis and Pat Henderson of the University of Alabama. Croneis and Henderson performed a content analysis of job titles as advertised in College $\mathcal{E}$ Research Libraries News between January 1990 and December 2000.26 Their research revealed that there was a dramatic increase in the number of position announcements with the word "electronic" or "digital" in the title during this eleven-year period. They also reported that, as libraries and librarians acquire more experience with electronic resources and digital projects, more functional areas throughout the institution are involved..$^{27}$ Therefore, not only does the progression of technology seem to be introducing more opportunities for project-based work in libraries, but the increased complexity caused by a project's need for expertise from multiple departments leads to an increased need for project management skills in modern librarian jobs. Croneis and Henderson state further that, while jobs with the word "electronic" in the title tend to be more traditional and user-centered, jobs with "digital" in the title tend to be "primarily responsible for administration and project management with emphases on securing funding and overseeing production." 28

Conversations among the digital reference implementation team, punctuated with anecdotal evidence as well as journal articles, gave rise to two primary questions. First, is the profession of librarianship really experiencing an increased demand for project management skills as evident through, for example, required qualifications listed in librarian job announcements? And second, assuming that project management skills are important for librarians, is project management currently being taught in library science master's degree programs?
In fall 2003, the digital reference implementation team leader and the author, also a team member, prepared a presentation about project management skills for the Virtual Reference Desk conference. A brief survey was e-mailed to 47 ALA-accredited master's degree programs, asking if project management was addressed in the institution's library science curriculum. Of the 26 replies that were received, 21 library science programs reported that at least one course in their library science master's curriculum addressed project management. One institution reported that several courses included project management, and one institution reported that one course was entirely dedicated to the topic, although the course was not mandatory for the MLS. In follow-up to the brief e-mail survey, the librarians visited the Web sites of each institution that reported offering at least one course in the master's degree curriculum that touched upon project management. From these Web sites, it was found that only one course actually included the term "project management" in either the course title or the course description, which suggested that project management was not necessarily the primary focus of the courses. One institution additionally indicated that its curriculum committee was currently investigating the degree of coverage of project management in its library science curriculum, further supporting that this topic was of timely relevance. Similarly, Winston and Hoffman formally surveyed online information about curriculum and courses for ALAaccredited MLIS programs. ${ }^{29}$ They found that project management courses were included in the curricula of only 3.7 percent of the LIS programs surveyed. However, many project management skills are addressed by general management courses, or within specialized management courses such as human resources or financial management, so it is difficult to compute the exact level of project management training in MLIS curricula. Winston and Hoffman conclude that, even if libraries never implement full-scale project management at the 
organizational level, project management principles are important for librarians, and libraries must provide an appropriate level of support for those who have project management responsibilities. ${ }^{30}$

\section{Methodology}

To determine whether project management skills are in demand for librarians, the author decided to conduct a content analysis of several years of library job ads, and compare the numbers of times project management skills were included as required or desired qualifications. At first it seemed that the easiest way to conduct an analysis of job ads would be to use or obtain data from an online site that contained several years' worth of data, such as the University of Texas School of Information's iSchool JobWeb. ${ }^{31}$ The most obvious benefit of using such a site is the ease of keyword searchability, especially when compared with reading printed job ads. UT's JobWeb includes a search interface that allows for easy keyword searching, as well as the ability to limit results by criteria such as type of library or geographical location. However, this type of online site can tend to be a portal for regional jobs rather than representative of the industry, and online job sites usually do not maintain archives beyond a year or two into the past, since both job seekers and employers have a time-sensitive need for the site. Further, the methods by which online job sites obtain job ads can be inconsistent. For example, many of the position announcements on the JobWeb site arrive unsolicited from employers: that is, there is no guarantee that employers are consistent in their use of the site. Another problem with online LIS job sites is that it can be hard to separate the job announcements for librarians from the job announcements for IT professionals. Therefore, College and Research Libraries News (CERLN) was eventually selected as the source for data collection. CERLN is a well-established journal and has reached a level of credibility and readership such that academic libraries submit job announcements to $C \mathcal{E} R L N$ as a matter of routine. It would have been ideal if an archive of librarian position announcements in electronic format had been available from $C \mathcal{E} R L N$, but an examination of CERL New's Web site produced only the most recent three months of job ads, and a phone call to CERL News verified that job ads are not archived in electronic format. Therefore, print copies from the journal were used for data collection. To alleviate eyestrain and the tedium of reading through the hard copy of hundreds of job ads, three years of job ads (1993, 2003, and 2004) were scanned, and optical character recognition was performed on the page images. In this manner, 440 pages and 1,180 librarian position announcements were converted from hard copy into keyword-searchable electronic text.

An issue that arose quickly while examining job ads is that because the skills of a project manager are often hard to distinguish from the skills of a general manager, or at least overlap to a great degree, the requirement for project management skills could be hidden within a job announcement's wording. To avoid relying on the subjective interpretation of job skills, it was decided to examine only job ads that included "project" in their text. Therefore, the content analysis was conducted by using the "find" feature in Microsoft Word to identify all occurrences of the word "project" in the position announcements. Each instance of the word was highlighted, and the corresponding job ads were copied and pasted into a separate document for each year to separate them from the rest of the ads. Then the three files of project-related job ads were printed out for more detailed examination. After several scans of the "project" job ads, two main levels of project management for librarians emerged: direct responsibility for project management, and project involvement in a nonleadership role. A job ad was determined to indicate direct responsibility for project management if it included the phrase "project management" or "project manager," or 
if it included a strong indication that the position was responsible for managing projects in the absence of these phrases. Strong indication of project management was inferred from the nonadjacent occurrence in a sentence of the word "project" and at least one management-related word such as "management," "leadership," "coordination," "organization," or "implementation." A job was considered to include project involvement in a nonleadership role if its responsibilities included items such as "works on departmentwide special projects" or "participate in innovative library projects."

All job ads for all three years, including the ads requiring project management skills, were also analyzed according to their job type. The job type categories included technical services, public services, information technology, administrative, archives/special collections, and other.

\section{Results}

There were 482 job ads in 1993. Most of these job ads (46.5\%) were for public services positions, followed by technical services (23\%), administrative (13.9\%), archives/special collections ( $8 \%$ ), and other positions (2\%). (See figure 1.) Twenty of 1993's job ads (4.1\%) contained evidence that project management skills were required of the successful candidate, including five ads that included "project management" or "project manager," and fifteen ads that contained strong evidence that the job required project management skills without the use of the term "project management/manager" as a required or desired qualification. An additional twenty-three job ads (4.8\%) suggested that the positions would likely be involved in project work.

There were 338 CERLN job announcements in 2003. Public services positions again ranked first with $43.8 \%$ of job ads, followed by administrative positions $(19.8 \%)$, technical services (18.6\%), IT $(9.5 \%)$, archives/special collections $(6.8 \%)$, and other positions (1.5\%). Of 2003's job ads, $11.2 \%$ included requirements for project management skills, including 19 ads that used the term "project management" or "project manager," and 19 ads that included wording strongly suggesting a need for such skills without using the term "project manager/management." An additional 17 ads (5\%) suggested that

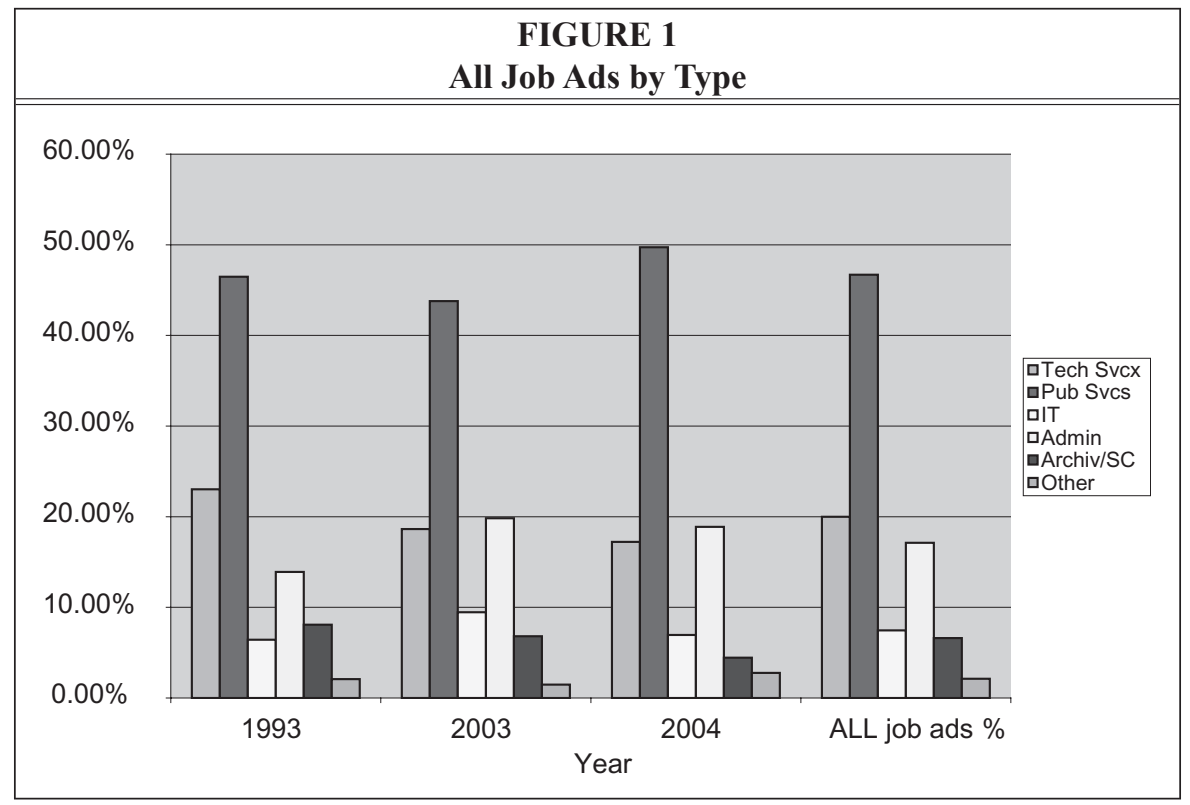




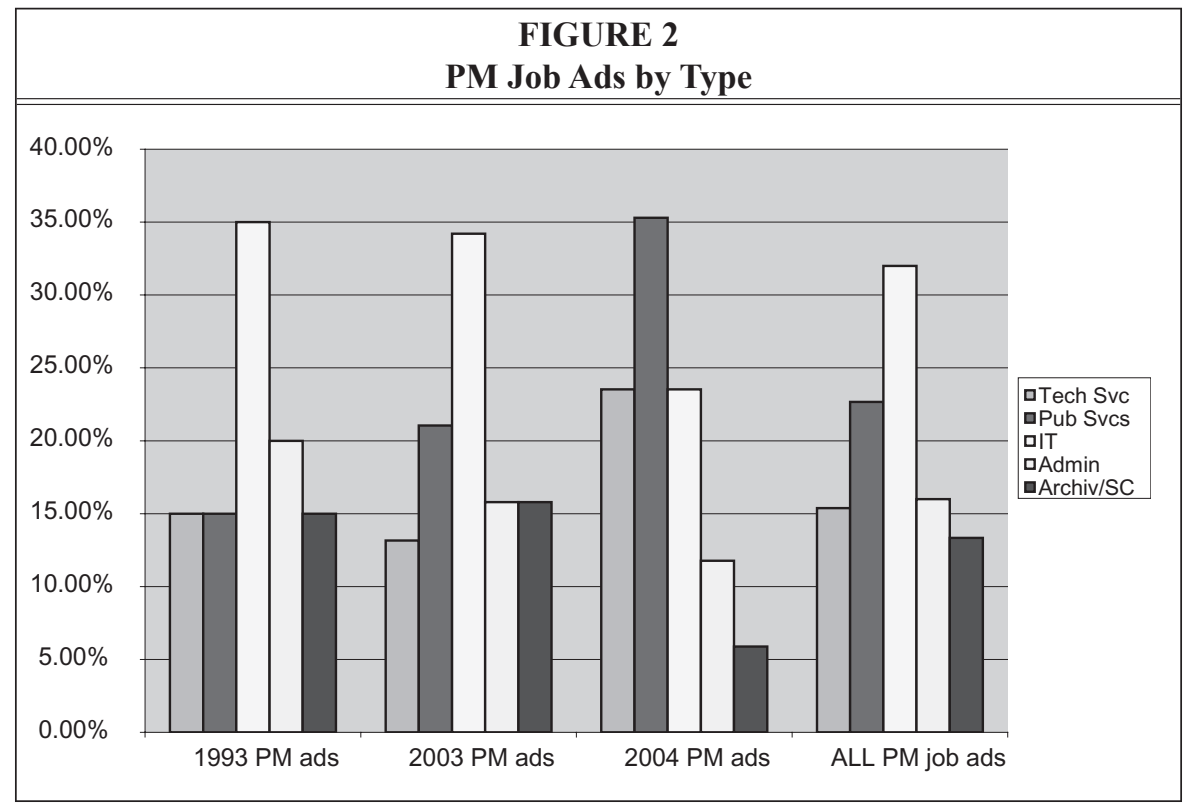

the position in question would likely be involved in some project work.

A total of 360 job ads from 2004 were also analyzed. Of these ads, $49.7 \%$ represented public services jobs, $18.9 \%$ administrative, $17.2 \%$ technical services, $6.9 \%$ IT, $4.4 \%$ archives/special collections, and $2.78 \%$ other. Seven of 2004's job ads used the term "project management" or "project manager," and ten ads provided strong evidence that project management skills were required, for a total of $4.7 \%$ of the ads. Nineteen of the ads, or $5.3 \%$, provided evidence that some involvement in project work would be expected.

While the highest number of job ads for each year related to public services positions, job type categories for second and third places shifted between 1993 and 2003-2004. In 1993, technical services trailed public services, but a decade later administrative positions replaced technical services jobs, which had dropped $5 \%-6 \%$, as the second largest portion of overall job ads. Further, IT jobs, which had ranked fifth in 1993 after fourth-place archives/special collections, gained slightly to overtake archives/special collections jobs, which in turn had dropped in the intervening decade.
Project management-related job ads differed markedly from overall job ads with regard to job type. While a majority of all job ads corresponded to public services jobs, the largest percentage of total project management jobs corresponded to IT positions. (See figure 2.) In 1993, IT jobs comprised $35 \%$ of project management job ads, followed by administrative $(20 \%)$, and technical services, public services, and archives/special collections jobs at $15 \%$ each. This pattern was roughly repeated in 2003 , with $34.2 \%$ of project management jobs coming from IT positions, followed by public services (21\%), administrative and archives/special collections (15.8\% each), and technical services (13.2\%). However, in 2004 public services jobs required more project management skills, with $35.3 \%$ of the project management job ads. IT dropped to second place in 2004, tying technical services jobs at $23.5 \%$ of PM job ads, followed by administrative (11.8\%) and archives/special collections positions (5.9\%).

\section{Discussion}

The total number of job ads decreased in the decade between 1993 and 2003. Total job ads per year fell from 482 in 1993 to 
338 in 2003, a decrease of $30 \%$. The count for total job ads in 2004 was 360, a drop of $25 \%$ from 1993. Possible causes of the decline include fewer jobs available, as well as possible migration to online-only job ads for some organizations.

The number of job ads explicitly requiring project management skills increased greatly between 1993 and 2003, from $4.1 \%$ to $11.2 \%$. However, project management-related librarian jobs fell again in 2004 , back to $4.7 \%$. Therefore, it is difficult to determine if there is a greater demand for project management skills now as compared with several years ago, or if 2003 was an abnormally rich year for job seekers with project management skills. One difference between the job ads of 1993 and those of 2003-2004 is the proportion of ads using the terms "project management" or "project manager" to the number of ads describing project management skills without these terms. For example, in 1993, five job ads used either "project management" or "project manager," compared to fifteen job ads with phrases such as "provide leadership in planning, developing, and implementing ongoing activities and special projects within the department" that imply project management. By 2003 there was a one-to-one correspondence, with 19 ads using "project management" or "project manager" and 19 ads implying project management through other terminology. In 2004, this ratio was 7:10, indicating that, even though the percentage of jobs requiring project management skills was roughly the same as in 1993, libraries were using the terms "project management" and "project manager" with greater frequency than eleven years before.

\section{Conclusions}

Based on surveys of both librarian job ads and MLIS curricula, it is clear that project management in libraries is here to stay. The technological aspect of most librarian jobs continues to grow, and technologybased projects in libraries can no longer be performed by an individual or a few staff members in one department-implementation of technology-based projects requires expertise from across the library. While it may seem unlikely that library organizational structures will evolve to support programs of multiple concurrent projects to the same extent as other predominantly project-oriented industries, such as construction, software development, or pharmaceuticals, the increased interdependence across multiple library units that is required for successful implementation of diverse initiatives ensures that librarians and other staff will continue to come together on project teams to get things done. The prediction that project management is and will remain an important aspect of library management is supported not only by the increasing body of literature concerning project management in libraries, but also by the training and continuing education sessions offered by library professional associations.

Both the Association of Research Libraries (ARL) and the Library Administration and Management Association offer regional institutes on project management, and ARL has published a 2005 SPEC Kit on managing large projects. The Special Libraries Association has supported PM education through articles published in Information Outlook, seminars offered through its Virtual Seminar Series and Click University, and continuing education coursed offered at the annual conferences. Clearly, the visionaries of the profession have noticed the growing importance of project management and are taking steps to help make librarians better project managers.

The results of this research have implications for library science graduate students, library administrators, and practicing librarians. First, librarians in training may find that their MLS/MLIS curriculum offers a course, and possibly courses, in project management. If PM courses are not offered by their home department, interested students can seek out project management training by cross-registering 
in a department that offers PM, such as the information science or management department, or by proposing a course of independent study. If taking a project management course proves to be too impractical, library science students can take solace in the fact that strong general management skills underpin project management skills, and most ALA-accredited MLIS curricula require at least one general management course.

Library administrators must think carefully about whom to appoint to manage a new project. The right person for the job may not be the "obvious" choice. A librarian who is creative and enthusiastic may lack the requisite organizational skills of a good project manager, while another who is highly organized and productive may need to improve interpersonal skills. It is likely that any good candidate will need remediation in at least a few of the key competency areas. And since most librarians have not received formal training in project management, it is incumbent upon administrators to make PM training available to potential leaders, either by bringing in a PM specialist or regional institute for staff development or by sending potential project managers out for training. Finally, if the failure of a particular project would result in a substantial negative impact, economic or otherwise, library administrators should seriously consider hiring a professional project manager for the job.

Practicing librarians often find themselves members of a project team, and eventually some are expected to step into the role of project manager. To prepare for such a duty, librarians can rely on numerous resources. First, the body of literature about desirable project management skills is quite rich, reflecting the fact that many project managers learn their jobs by doing, rather than through formal training.
In addition to reading, interested librarians should also avail themselves of any available training and, if necessary, suggest to their administration that a series of training sessions on project management could be cost effective, especially if a major systemwide project is looming on the horizon. At any rate, librarians who enjoy a good challenge and a chance to step outside their comfort zone should find ample opportunities for both by expressing interest in managing a project. A job well done will benefit the organization and may well chart the fledgling project manager on a fascinating new career course in librarianship.

The research presented in this paper analyzed only three years of librarian job ads. To more accurately document trends in project management skills or other job responsibilities for librarians, a more detailed study of librarian position announcements should be performed. Multiple data sources could be considered, as well as a greater number of years of data. One impediment to such a study is the amount of time required for scanning journal pages, performing optical character recognition, and searching the resulting files for keywords and phrases. To this end, it would be useful if reputable library science journals such as $C \mathcal{E} R L N$ and American Libraries maintained an archive of electronic job ads for research purposes. Content analysis of job ads is a tool that can be used in diverse ways to characterize our profession and inform decisions about MLIS curriculum planning, on-the-job training needs, and human resources issues. It would be fitting if the leading professional journals of our field took steps to facilitate research about librarianship by electronically archiving librarian position announcements in addition to other content.

\section{Notes}

1. Mark D. Winston and Tara Hoffman, "Project Management and Libraries," Journal of Library Administration 42, no. 1 (Feb. 2005): 51-61.

2. Wideman Comparative Glossary of Project Management Terms v.3.1, Project Management 
(updated Dec. 19, 2002). Available online from http://maxwideman.com/pmglossary/PMG_P12. htm. [Accessed 25 January 2005].

3. David I. Cleland, Project Management: Strategic Design and Implementation, 3rd ed. (New York: McGraw-Hill, 1999).

4. Project Management Institute, About PM. Available online from http://www.pmi.org/info/ AP_IntroOverview.asp?nav=0201. [Accessed 27 January 2006.]

5. Association for Project Management, About Us. Available from http://www.apm.org. uk/page.asp? categoryID $=1 \&$ subCategory $I D=11$ \&pageID $=0$. [Accessed 27 January 2006.] International Project Management Association, About Us. Available online from http://www.ipma. ch/asp/default.asp? $\mathrm{p}=89$. [Accessed 27 January 2006.]

6. Project Management Institute, New Accreditation Policy for Degrees in Project Management. Available online from http://www.pmi.org/info/PDC_AccreditationOverview.asp?nav=0407. [Accessed 27 January 2006.] American Academy of Project Management, Certification. Available online from http://www.projectmanagementcertification.org/certification.html. [Accessed 27 January 2006.]

7. International Association of Project and Program Management, CPM Certification. Available online from http://www.iappm.org/cpm.htm. [Accessed 27 January 2006.]

8. Project Management Institute, A Guide to the Project Management Body of Knowledge, 3rd ed. (Newtown Square, Pa.: Project Management Institute, Inc., 2004).

9. Michael Greer, "Essential Skills for Today's 'Instant' Project Managers," Performance Improvement (Feb. 1998), 24-29.

10. Ibid.

11. Ibid.

12. S. El-Sabaa, "The Skills and Career Path of an Effective Project Manager," International Journal of Project Management 19 (2001), 1-7. 64.

13. Bart Bolton, "10 Tips for Becoming a Successful Manager," InformationWeek, no. 1025 (2005),

14. James Taylor, A Survival Guide for Project Managers (New York: American Management Association, 1998).

15. Ibid., 15.

16. Barry Z. Posner, "What It Takes to Be a Good Project Manager," Project Management Journal (March 1987). Quoted in James Taylor, A Survival Guide for Project Managers (New York: American Management Association, 1998), 11-16.

17. Ibid., $12-13$.

18. Taylor, 18.

19. H. Frank Cervone, "How Not to Run a Digital Library Project," OCLC Systems \& Services 20, no. 4 (2004): 162-66.

20. H. Frank Cervone, "Making Decisions: Methods for Digital Library Project Teams," OCLC Systems \& Services 21, no. 1 (2005): 30-35.

21. H. Frank Cervone, "Influencing: A Critical Skill for Managing Digital Library Project Teams," OCLC Systems \& Services 21, no. 2 (2005).

22. Ibid., 106.

23. Ibid., 109.

24. Marlene Garstang, “Checklists for Training Project Management: The Team's Perspective,” Journal of Instruction Delivery Systems (Winter 1994): 29-33.

25. Ibid., 29.

26. Karen Croneis and Pat Henderson, "Electronic and Digital Librarian Positions: A Content Analysis of Announcements from 1990 through 2000," Journal of Academic Librarianship 28, no. 4 (July 2002): 232-37.

27. Ibid., 234-35.

28. Ibid., 235.

29. Mark Winston and Tara Hoffman, Project Management in Libraries.

30. Ibid., 60.

31. University of Texas School of Information, JobWeb. Available online at http://www.ischool. utexas.edu/jobweb/. [Accessed 27 January 2006.] 